\title{
AIM FOR THE BEST, PREPARE FOR THE WORST: INDIANA'S LACK OF MUNICIPAL BANKRUPTCY
}

\author{
KyLE Montrose*
}

\section{INTRODUCTION}

Imagine it, you get off late from work and are driving home when suddenly you are blindsided by another vehicle ramming into your passenger side at a high speed. Shaken, you notice the street and intersection lights are completely out. A young woman is pinned to her driver's seat by the dashboard of her car. From her screams, you can tell she is in pain. You pull out your cell phone, doing all you feel you can do, dial 9-1-1 and let the woman know help should be there soon. You wait. Finally, an operator answers. You desperately tell her what happened, ask that help be dispatched immediately, and hang up. You wait. You wait. The woman falls unconscious.

An hour later, an ambulance arrives. Desperate for answers, you ask what took so long. As four men rush to analyze the scene, the driver responds. He tells you that thirty minutes after you called, another ambulance was dispatched but broke down on the way. He gestures to his dashboard, inviting you to read the odometer-250,000 miles. Speaks for itself, you quietly think as you walk away.

As unfortunate as it may be, the circumstances giving way for this narrative have been a reality for metropolises. ${ }^{1}$ Areas of the country such as New York City, Orange County, Detroit, Birmingham, and others have all faced the harsh reality of lurking financial uncertainty. ${ }^{2}$ The repercussions of economic downturn, poor investment choices, or one-time disasters have impacts beyond a company's bottom line or an individual's solvency. ${ }^{3}$ When cities, utility services, facility agencies, hospitals, and schools face economic straits, everyone is at risk and the various externalities are limitless. ${ }^{4}$ Just like individuals and companies, municipalities sometimes need a fresh start-an opportunity to reorganize and get out from underneath crippling debt to a point where repayment is possible. ${ }^{5}$

* J.D. Candidate, 2017, Indiana University Robert H. McKinney School of Law; MBA Candidate, 2018 University of Cincinnati Carl H. Lindner School of Business; B.A., 2014, Miami University. A special thanks to Professor and former Indiana Supreme Court Justice Frank Sullivan for his critical review throughout the Note writing process and continued effect on my legal education; Professor Max Huffman and Ms. Kathryn S. Cannon, Esq. each for their distinct impact on my topic selection; and all my friends, family, and mentors for their continued love and support.

1. See generally In re City of Detroit, 504 B.R. 97 (Bankr. E.D. Mich. 2013).

2. See generally Michael De Angelis \& Xiawei Tian, United States: Chapter 9 Municipal Bankruptcy-Utilization, Avoidance, and Impact, in UntIL DeBT Do Us PART 311 (Otaviano Canuto \& Lili Liu eds., 2013).

3. See generally In re City of Detroit, 504 B.R. 97; Kevin Drum, How the Scam Works, Mother JONES (Mar. 2010), http://www.motherjones.com/kevin-drum/2010/03/how-scam-works [perma.cc/P9ZE-YPXV].

4. See De Angelis \& Tian, supra note 2.

5. See generally James E. Spiotto, Chapman and Cutler LlP, Primer on Municipal

http://doi.org/10.18060/4806.1151 
Where municipalities are different than individuals and companies is in municipalities' responsibilities. ${ }^{6}$ A municipality is not solely responsible to one family or one set of shareholders. ${ }^{7}$ Rather, a municipality has an unavoidable duty to all its constituents living with and needing essential services. ${ }^{8}$

Chapter 9 of the federal Bankruptcy Code offers municipalities relief from debt that would otherwise cripple a municipality's ability to carry out fiduciary functions. ${ }^{9}$ However, in accordance with the Tenth Amendment, the federal government cannot force a state to conduct its affairs in a certain manner or enforce federal law. ${ }^{10}$ A state must specifically authorize its municipalities to be a Chapter 9 debtor through its legislature. ${ }^{11}$ Although recent Indiana senate bills have proposed authorizing Chapter 9 relief, ${ }^{12}$ Indiana is still among twenty-two states where municipal bankruptcy is not permitted. ${ }^{13}$

In part as a result of economic downturn, the scale of recent filings throughout the twenty-eight states allowing municipal bankruptcy caught the national spotlight and re-opened the discussion regarding Chapter 9.

This Note will draw a conditional conclusion that Indiana should authorize municipal bankruptcy. The condition to authorization is inclusion of key protections to ensure the "tool" is only used under circumstances likely to benefit a municipality's long-term economic health and not lead to recurrent financial failure. Part I of this Note briefly describes landmark examples of municipal bankruptcy, the reasons for their filings, and their ultimate success or relative failure. Part II explains the constitutionality of Chapter 9, how it works, and provides relevant statistics. Part III specifically analyzes Chapter 9's costs and benefits as well as the beneficial or detrimental reasons for filing. Lastly, in light of the foregoing analysis, Part IV looks to Indiana's current financial state and system of aid for economically distressed areas, finally proposing certain concepts of protective clauses to be included should Indiana decide to adopt Chapter 9.

\section{OVERVIEW OF LANDMARK MUNicipal BANKRUPTCY FILINGS}

Citizens of premier cities feel a sense of confidence in the stability of their

Debt Adjustment-Chapter 9: The Last Resort For Financially Distressed Municipalities (2012), http://docplayer.net/1376437-Primer-on-municipal-debt-adjustmentchapter-9-the-last-resort-for-financially-distressed-municipalities.html [https://perma.cc/B4LLWZHT].

6. Id.

7. Id.

8. Id.

9. See 11 U.S.C. passim (2012).

10. See U.S. Const. amend. X.

11. 11 U.S.C. $\S 109(c)(2)(2012)$.

12. S.B. 105, 170th Gen. Assemb., Reg. Sess. (Ind. 2011).

13. State Policies on Chapter 9 Bankruptcy, News10.NeT, http://archive.news10. net/news/pdf/State-Policies-on-Chapter-9-bankruptcy.pdf [http://perma.cc/52NN-R5X6]. 
municipalities. ${ }^{14}$ In many instances, this sense of assurance is justified by past experience. ${ }^{15}$ But these thoughts of natural buoyancy can be shaken as citizens watch their city or other important municipal functions teeter on the brink of insolvency.

After hosting the 1964 World's Fair and emerging as an icon of American culture, innovation, and pride, ${ }^{16} \mathrm{New}$ York City felt the effect of maintaining its social status during the $1970 \mathrm{~s} .{ }^{17}$ Cheap transit, expanded welfare, free college tuition, abundant cultural institutions, and social/health programs took their toll, causing the city's finances to crumble under amassing debt and a lessening middle-class tax base. ${ }^{18}$ The once stable lending market trembled, and routine financing necessary to maintaining the city's operations was no longer available. ${ }^{19}$ New York City was kept afloat through the state borrowing $\$ 400$ million for the city and by collecting early payment of $\$ 600$ million in taxes from wealthy property owners. ${ }^{20}$ An emergency Financial Control Board and the federal government eventually bailed the city out with $\$ 2.5$ billion in federal loan guarantees. ${ }^{21}$ Although federal aid was given, it did not come easily and followed controversy over President Ford vowing to veto any bill offered to bail out New York City. ${ }^{22}$

There is no sure way to determine when a city has become too big to fail, but many fine municipalities like Birmingham, Detroit, Orange County, and San Bernardino have filed without receiving such aid. ${ }^{23}$ Specifically, Detroit, Michigan, recently filed for Chapter 9 relief. ${ }^{24}$ Partially a result of the economic crisis in 2008-2009, rampant unemployment from lessening industrial work caused a shortage in the revenue stream as the tax base continued to shrink. ${ }^{25}$ The appropriate sums of money were not available to provide essential services to citizens, crime increased, and the physical and technological infrastructures began to crumble. ${ }^{26}$ The city made efforts to improve its finances without success, and

14. See De Angelis \& Tian, supra note 2 .

15. See id.

16. Bill Young, The Story of the 1964/1965 New York World's Fair, NYwF64.Com, http://www.nywf64.com/fair_story01.shtml [http://perma.cc/3CPX-RFXW] (last visited Jan. 31, 2017).

17. Justice Frank Sullivan, Jr., Professor, Lecture at Indiana University Robert H. McKinney School of Law: Creditors' Rights and Two Indiana Government Finance Projects (Apr. 7, 2009).

18. Id.

19. $I d$.

20. $I d$.

21. Id.

22. Frank Van Riper, Ford to City: Drop Dead in 1975, N.Y. DAILY News, Oct. 29, 2015, http://www.nydailynews.com/new-york/president-ford-announces-won-bailout-nyc-1975-article1.2405985 [perma.cc/PD7M-UVPE].

23. See De Angelis \& Tian, supra note 2, at 328-39.

24. See In re City of Detroit, 504 B.R. 97, 128 (Bankr. E.D. Mich. 2013).

25. Id. at 113-14.

26. Id. at 113-14, 119-21. 
eventually filed in good faith, seeking to protect its citizens from the externalities of an insolvent municipality. ${ }^{27}$ Breaking records for the largest municipal bankruptcy filing to date, Detroit sought relief from nearly $\$ 15$ billion spread between 100,000 debtors. ${ }^{28}$

Many municipalities felt the effects of the financial crisis. ${ }^{29}$ Some, like Detroit, felt reverberations throughout the entire municipality $;^{30}$ others felt the effect on particular transactions or investment strategies. ${ }^{31}$ Jefferson County, Alabama, felt the effect by way of interest rates on municipal bond debt incurred to fund a project. ${ }^{32}$ Market destabilization during the Great Recession led to illiquidity. ${ }^{33}$ Debt restricting interest rate swap agreements became useless, ultimately leading to default on payments and acceleration of the remaining principle.$^{34}$ Another example is Orange County, which, in response to California's Proposition 13, made creative investments that were devalued by market conditions leading to a net loss when forced to borrow for incurred liabilities. ${ }^{35}$ These two municipalities, both of which exceeded fiscal records when they filed for Chapter 9 relief, are not the normal model of a bankrupt city. ${ }^{36}$ The more typical conception are areas like Prichard, Alabama, the "classic case of a dying city." ${ }^{37}$ Prichard County filed bankruptcy due to the closure of a military base, declining property values, and a shift in the commerce structure toward surrounding suburbs. ${ }^{38}$

The foregoing examples have been largely related to city and local governments' need for debt relief. However, other quasi-governmental entities like utilities, transportation, and school districts can file Chapter 9. ${ }^{39}$ A key example of a public utility in need of relief was the Washington Public Power Supply System ("WPPSS"), which, with authority to issue revenue bonds, borrowed $\$ 2.25$ billion to construct two nuclear power generating plants. ${ }^{40}$ Due to underestimated costs, WPPSS terminated the project. ${ }^{41} \mathrm{~A}$ similar situation occurred in Indiana with the abandonment of a $\$ 2.5$ million project to build

27. See id.

28. Id. at 113-14.

29. See De Angelis \& Tian, supra note 2, at 328-29.

30. See In re City of Detroit, 504 B.R. at 97.

31. See De Angelis \& Tian, supra note 2, at 328-29.

32. Id.

33. Id.

34. Shelly Sigo, Jefferson County Has 1st Missed Payment, Bond BuYER (July 9, 2009), http://www.bondbuyer.com/issues/118_130/-305183-1.html [http://perma.cc/G96G-KW83].

35. De Angelis \& Tian, supra note 2, at 328-39; Sullivan, supra note 17; see also In re Cty. of Orange, 179 B.R. 185 (Bankr. C.D. Cal. 1995).

36. De Angelis \& Tian, supra note 2, at 328-39.

37. Id. at 326-28; Sullivan, supra note 17.

38. De Angelis \& Tian, supra note 2, at 331.

39. See id.

40. Sullivan, supra note 17.

41. Id. 
Marble Hill Nuclear Power Station in Saluda Township. ${ }^{42}$ Due to the denial of a utility rate increase to recover the investment from ratepayers, the investor-owned municipal utility defaulted on its bonds, leading to a significant loss to investors. ${ }^{43}$

In sum, municipal bankruptcy can come about in many ways and can be used by different municipal actors. ${ }^{44}$ The need to file can arise from financial mismanagement, improper risk assessment, or result from government's businesslike operations. ${ }^{45}$ Others are caused by market conditions, economic decline, and general fiscal decay in a region where the municipality is located. ${ }^{46}$ By definition, cities, towns, and local governments are municipal actors, but school districts, transportation, and other government service agencies like public utilities can qualify for relief as well. ${ }^{47}$ The diversity of entities subject to municipal bankruptcy is a key consideration in analyzing Chapter 9's intricacies and policy arguments in either direction. It is also important to keep in mind the availability of these circumstances to otherwise fiscally responsible entities and bankruptcy's prevalence among highly regarded flagship cities. Theoretically, no municipality is above the need for debt relief. ${ }^{48}$ Part II explains the constitutionality of Chapter 9 bankruptcy and how it works.

\section{CHAPTER 9 BANKRUPTCY}

Chapter 9 is very similar to other avenues for relief provided by the Bankruptcy Code, and in certain ways is also extremely different. ${ }^{49}$ Right off the line, the federal code subordinates itself to the state's definition of a municipality in the required authorization to be a debtor, ${ }^{50}$ raising constitutional eyebrows ${ }^{51}$ Before diving into the constitutionality and intricacies of Chapter 9, it is important to lay a foundation for bankruptcy as a whole.

\section{A. Overview of Bankruptcy}

The federal Bankruptcy Code is in place as a means to provide debtors with

42. Id.; Jesus Rangel, Half-Built Indiana Nuclear Plant Abandoned at a 2.5 Billion Cost, N.Y. Times (Jan. 17, 1984), http://www.nytimes.com/1984/01/17/us/half-built-indiana-nuclearplant-abandoned-at-a-2.5-billion-cost.html [http://perma.cc/BNM6-YSVH].

43. Rangel, supra note 42.

44. Sullivan, supra note 17.

45. When Government Fails: The Orange County Bankruptcy, Pub. PoL'y InST. CAL. (Mar. 18, 1998), http://www.ppic.org/content/pubs/op/OP_398OP.pdf [http://perma.cc/6J4B-XJJE].

46. De Angelis \& Tian, supra note 2, at 328-29.

47. Sullivan, supra note 17.

48. Telephone Interview with Jack Martin, Emergency Manager of Gary Community Schools and Partner at Martin, Arrington, Desai and Meyers, in Martinsville, Ind. (Jan. 22, 2016) [hereinafter Martin Interview].

49. See 11 U.S.C. $\S \S 901-46$ (2012).

50. Id.

51. See generally Stellwagen v. Clum, 245 U.S. 605 (1918). 
solace from crippling debt. ${ }^{52}$ The Code allows individuals, businesses, and, in twenty-eight states, municipal debtors to reform their financial situation and become beneficial contributors to society. ${ }^{53}$ Two main tenets inform the structure and provisions of the code; a fresh start and equity of distribution. ${ }^{54}$

Embodied by discharge from obligations, the fresh start intends to pardon debt incurred prior to filing for relief. ${ }^{55}$ Every Chapter includes provisions for discharge at varying times, following liquidation and distribution of assets, ${ }^{56}$ confirmation, ${ }^{57}$ or completion of the plan of reorganization. ${ }^{58}$ Under any Chapter, the idea is to allow the debtor a clean slate when emerging from bankruptcy to regain the debtor's financial footing and rejoin society free of accruing interest. ${ }^{59}$ While in a bankruptcy proceeding, the automatic stay acts as a pre-confirmation fresh start relieving the debtor of all creditor action to recover debts. ${ }^{60}$

Equity of distribution is in place as a protection for both creditors and debtors. ${ }^{61}$ Creditors benefit from equitable distribution, ensuring they receive what was otherwise expected in the event of default. ${ }^{62}$ Although not necessarily fair, creditors likely receive less than if bankruptcy had not occurred ${ }^{63}$ However, creditors receive impartial treatment and a proportion of the debtor's assets or earnings; while total non-payment of the obligations would allow them no return whatsoever. ${ }^{64}$ By ensuring creditors receive some return on lending, the Code also keeps creditors from raising interest rates to account for risk in lending. ${ }^{65}$ This allows debtors the benefit of financing without prohibitive costs and interest associated with the obligation. ${ }^{66}$

Debtors can seek relief through five different chapters of the Bankruptcy Code. As a general matter, Chapters 7 and 11 are available to businesses and individuals, Chapter 12 is reserved for farmers and fisherman, Chapter 13 is reserved for consumers, and Chapter 9 is reserved for municipalities authorized by state law to be a debtor. ${ }^{67}$ This Note primarily looks at Chapter 9 .

52. See 11 U.S.C. $\S 524$ (2012).

53. Id. $\S 109$.

54. David Epstein et Al., Bankruptcy: Dealing with Financial Failure for INDIVIDUALS AND BUSINESSES 37-52 (4th ed. 2015).

55. 11 U.S.C. $\S 524$ (2012).

56. Id. $\S 727$.

57. Id. $\S 1141$.

58. $I d . \S 1328$.

59. EPSTEIN ET AL., supra note 54, at 37.

60. See 11 U.S.C. $\S 362$ (2012).

61. EPSTEIN ET AL., supra note 54, at 51.

62. $I d$. at 52 .

63. Id. at 51-52.

64. Id. at 52 .

65. Stephen Ross et Al., Corporate Finance 482-83 (Michele Janicek ed., 3d ed. 2014); see EPSTEIN ET AL., supra note 54, at 51-52.

66. EPSTEIN ET AL., supra note 54, at 51; Ross ET AL., supra note 65, at 483.

67. 11 U.S.C. $\S 109$ (2012). 


\section{B. Constitutionality of Chapter 9}

In proceedings under Chapter 9, three constitutional issues can arise: conforming with the uniformity requirement of the Bankruptcy Clause, adherence to the Contracts Clause, and infringement upon the Tenth Amendment. ${ }^{68}$

The United States Constitution, Article I, Section 8, Clause 4 states Congress shall establish "uniform Laws on the subject of Bankruptcies throughout the United States." 69 Concern arises regarding Chapter 9 where the Code leaves it to states to determine what qualifies as a municipality, naturally leading to different results. ${ }^{70}$ In two different Supreme Court cases, the issue of uniformity was raised. $^{71}$ The first acknowledged the Bankruptcy Code may lead to "different results in different states." 72 A subsequent case held the requirement of uniformity does not divest Congress of the power to allow states to account for locally isolated problems. ${ }^{73}$ It follows that as long as the federal law applies uniformly among classes of individuals $\mathrm{s}^{74}$ and the treatment of classes is equal, the outcome does not destroy uniformity. ${ }^{75}$ Under the Bankruptcy Code, Chapter 9 debtors are those that meet eligibility requirements, including having been specifically authorized under state law. ${ }^{76}$ Where the application of federal law is to abide by state law, the federal law remains uniform and is not unconstitutional. ${ }^{77}$

The Contracts Clause, which is Article I, Section 10, Clause 1 of the Constitution, prohibits states from passing laws "impairing the Obligation of Contracts."78 However, the Bankruptcy Code is federal law and, although the prohibition of impairment applies to states, ${ }^{79}$ it does not forbid Congressional action. ${ }^{80}$ The controversy regarding municipal bankruptcy is state authorization of a debtor tangentially affecting contracts and determining which may be impaired. ${ }^{81}$ Even though this authorization may come from the states, the confirmation and actual impairment is still prescribed by federal law and carried

68. See In re City of Detroit, 504 B.R. 97 (Bankr. E.D. Mich. 2013).

69. U.S. Const. art. I, § 8, cl. 4; see also Municipal Bankruptcy, The Tenth Amendment and The New Federalism, 89 HARV. L. REV. 1871, 1900-02 (1976).

70. See Stellwagen v. Clum, 245 U.S. 605, 613 (1918); see also 11 U.S.C. § 109(c)(1)

(2012); Blanchette v. Conn. Gen. Ins., Corps., 419 U.S. 102, 159 (1974).

71. Blanchette, 419 U.S. at 159; Stellwagen, 245 U.S. at 613.

72. Stellwagen, 245 U.S. at 613 .

73. Blanchette, 419 U.S. at 159.

74. Schultz v. United States, 529 F.3d 343, 351 (6th Cir. 2008).

75. In re Schafer, 689 F.3d 601, 611 (6th Cir. 2012).

76. 11 U.S.C. $\S 109$ (c) (2012).

77. See generally In re City of Detroit, 504 B.R. 97 (Bankr. E.D. Mich. 2013).

78. U.S. ConsT., art. I, § 10, cl. 1; see Sturges v. Crowninshield, 17 U.S. 122 (1819); see also Tr. of Dartmouth Coll. v. Woodward, 17 U.S. 518 (1819).

79. Sturges, 17 U.S. at 191; see also Tr. of Dartmouth Coll., 17 U.S. 518.

80. In re Sanitary \& Imp. Dist., No. 7, 98 B.R. 970, 972 (Bankr. D. Neb. 1989).

81. See generally id. at 970 . 
out by the federal judiciary. ${ }^{82}$

The Tenth Amendment to the United States Constitution reserves the powers not delegated to the federal government or prohibited to be exercised by the states, to, "the States respectively, or to the people." Amendment is used to incorporate any implied limitation on Congressional power to control state activity. ${ }^{84}$ One such implied power is the ability to carry out statelevel financial activities without federal interference. ${ }^{85}$ It is the "essence of sovereignty" to make contracts and determine the exercise of governmental enforcement. ${ }^{86}$ States retain the power to do so as long as they have not been preempted by federal law. ${ }^{87}$ Reaching an equilibrium between the states and federal government has proved difficult, but as it pertains to the Bankruptcy Code and municipal bankruptcy controversy, it has largely settled. ${ }^{88}$

In 1974, pursuant to Commerce Clause powers, Congress extended workforce protections to all state employees. ${ }^{89}$ The Supreme Court found the provisions impaired the reserved freedom of states to structure their internal operations with regard to traditional functions, like allowing contractual relations among private citizens..$^{90}$ Similarly, in 1985 Congress passed legislation imposing "incentives" to state level compliance with federal law, including a "take title" provision..$^{91}$ The Supreme Court found the "take title" provision unconstitutional as tantamount to requiring governance according to federal instruction, forcing the hand of local governments in violation of the Tenth Amendment. ${ }^{92}$ Although Congress is allowed to offer states a choice and even incentivize their decision to follow federal standards,${ }^{93}$ legislation is unconstitutional when it commandeers the states. ${ }^{94}$ The Court again reinforced these principles by finding Congressional action in violation of the Tenth Amendment when imposing a "mandatory obligation" on the state executive to act pursuant to federal law. ${ }^{95}$

Pertaining to Chapter 9 of the Bankruptcy Code, Congress does not violate

82. Id. at 973 .

83. U.S. CONST. amend. X.

84. See South Carolina v. Baker, 485 U.S. 505, 511 (1988).

85. See, e.g., Printz v. United States, 521 U.S. 898 (1997); New York v. United States, 505 U.S. 144 (1992); Nat'1 League of Cities v. Usery, 426 U.S. 833 (1976), overruled by Garcia v. San Antonio Metro. Transit Auth., 469 U.S. 528 (1985); see also Garcia v. San Antonio Metro. Transit Auth., 469 U.S. 528 (1985).

86. United States v. Bekins, 304 U.S. 27, 51-52 (1938).

87. Id.

88. See In re City of Detroit, 504 B.R. 97, 141-54 (Bankr. E.D. Mich. 2013).

89. Garcia v. San Antonio Metro. Transit Auth., 469 U.S. 528, 533 (1985).

90. See Nat'l League of Cities, 426 U.S. 794.

91. New York v. United States, 505 U.S. 144, 152-53 (1992).

92. Id. at $162,174-75$.

93. Id. at $174-75$.

94. Id. at 175-76.

95. Printz v. United States, 521 U.S. 898, 933 (1997). 
the Tenth Amendment. ${ }^{96}$ By not imposing a "mandatory obligation" to authorize, but rather making the decision a permissible pre-requisite to seeking relief, Congress acts within Constitutional bounds. ${ }^{97}$ Where the consent of states is required to be governed by federal law, imposing restrictions and implementing rules otherwise traditionally governed by state-held powers is permissible. ${ }^{98}$ Furthermore, state authorities retain control over "governmental powers of [the] municipality," $" 99$ and can thereby "remain accountable to their local electorate," free of federal intervention. ${ }^{100}$ House committee discussions regarding the 1978 amendment to Chapter 9 stated one saving grace is Section 904's prohibition of court interference with municipal decisions. ${ }^{101}$ In places where consent has been given, the federal government is sufficiently restricted in actions it can take affecting the local electorate and traditional state functions. ${ }^{102}$ With an understanding for the constitutionality of Chapter 9 , it is incumbent to understand how municipal bankruptcy functions and the protections Congress put in place.

\section{How Chapter 9 Works}

The general structure of the Bankruptcy Code pertaining to Chapter 9 appears a skeleton in comparison to other Chapters. ${ }^{103}$ Congress imposes restrictions, such as the reservation of state power to control municipalities, ${ }^{104}$ limitations on recourse,${ }^{105}$ and limitations on the jurisdiction and powers of the court, ${ }^{106}$ setting the appropriate bounds for Chapter 9. Other provisions, like the requirement of insolvency ${ }^{107}$ and prohibition of involuntary petitions, ${ }^{108}$ confine the debtor and may be seen as a way Congress passes subtle judgment on the use of Chapter 9 .

Unlike Chapters 7 and 11, only the debtor-a municipality-can file for relief; there can be no involuntary petitions. ${ }^{109}$ Upon filing, the debtor has the burden of proving, beyond a preponderance of the evidence, the satisfaction of eligibility under Section 109(c) of the Bankruptcy Code. ${ }^{110}$ One of the requirements unique to Chapter 9 is to show the municipality is insolvent,

96. In re City of Detroit, 504 B.R. 97, 141 (Bankr. E.D. Mich. 2013).

97. See 11 U.S.C. $§ 109(c)(2)$ (2012); Printz, 521 U.S. at 933.

98. See In re City of Vallejo, 403 B.R. 72, 75-76 (Bankr. E.D. Cal. 2009).

99. 11 U.S.C. $\S 903$ (2012); see also id. $\S 904$.

100. New York v. United States, 505 U.S. 144, 186 (1992).

101. H.R. Rep. No. 95-595, 95th Cong., 1st Sess. 398 (1977).

102. See In re City of Detroit, 504 B.R. 97 (Bankr. E.D. Mich. 2013); see also 11 U.S.C. $\S \S$ 901-46 (2012).

103. See generally 11 U.S.C. $\S \S 901-46$ (2012).

104. Id. $\S 903$.

105. Id. $\S 927$.

106. Id. $\$ 904$.

107. Id. $\S 109(\mathrm{c})(3)$.

108. Id. $\S 303$.

109. Id.

110. In re City of Vallejo, 408 B.R. 280, 289 (BAP 9th Cir. 2009). 
meaning it is "generally not paying" or is "unable to pay" its debts as they become due. ${ }^{111}$ The respective tests look to current or likely future nonpayment, ${ }^{112}$ requiring the municipality to be in "bona fide financial distress" unlikely to mend without the impairment of contracts. ${ }^{113}$ This requirement flows naturally from the effect of Chapter 9, which may be to impair contractual obligations. ${ }^{114}$ Generally, a municipality is held to a high standard and expected to not breach contracts. ${ }^{115}$ Accordingly, filing Chapter 9 bankruptcy should be an exercise of last resort, when all extra-judicial attempts have failed. ${ }^{116}$

Many states impose requirements for extra-judicial efforts. ${ }^{117}$ These provisions vary as states are given the power to tailor the legislation to the needs of their locality. ${ }^{118}$ Some provide for a single or multiple boards to examine the situation and make recommendations ${ }^{119}$ while other states provide conditions like express approval from the governor, ${ }^{120}$ or passage of an ordinance or resolution authorizing the instance. ${ }^{121}$ Other states provide fiscal requirements for ensuring the municipality is truly in financial ruin. ${ }^{122}$ Aside from these state-enacted gateways, the Code imposes a duty of good faith negotiation prior to allowing a petition. ${ }^{123}$ To satisfy the burden of proof, a debtor must show it cannot obtain an agreement through negotiations, showing good faith effort to no avail, impracticability, or reasonable belief a creditor will seek preferential treatment. ${ }^{124}$ When allowed and carried out, notice of the filing, order for relief, or dismissal shall be published at least once a week for three weeks in one newspaper of general circulation. ${ }^{125}$ The debtor is also required to file a list of creditors, ${ }^{126}$ the effect of which is to act as proof of claim unless the claim is marked "disputed, contingent, or unliquidated." ${ }^{127}$ The debtor is then required to submit a plan, ${ }^{128}$

111. 11 U.S.C. $\S 101(32)(c)(2012)$.

112. See In re City of Stockton, 493 B.R. 772, 778 (Bankr. E.D. Cal. 2013).

113. Id.

114. See 5 William L. Norton, JR., Bankr. L. \& Prac. 3d $\S 90: 6$ (West 2017).

115. Id.

116. Id.; Interview with Senator Ed Charbonneau, Indiana State Senator, in Indianapolis, Ind. (Nov. 16, 2015) (on record with author) [hereinafter Charbonneau Interview].

117. See generally In re City of Detroit, 504 B.R. 97 (Bankr. E.D. Mich. 2013).

118. See South Carolina v. Baker, 485 U.S. 505 (1988); see also U.S.CONST. amend X; United States v. Bekins, 304 U.S. 27 (1938).

119. See, e.g., In re City of Detroit, 504 B.R. at 124.

120. Conn. Gen. Stat. § 7-566 (2017).

121. Mont. CODE $\S 7-7-132$ (2015).

122. See, e.g., id.; Conn. Gen. STAT. § 7-566 (2017).

123. See 11 U.S.C. $\S 921$ (c) (2012).

124. In re Ellicott Sch. Bldg. Auth., 150 B.R. 261, 265-66 (Bankr. D. Colo. 1992).

125. 11 U.S.C. $\S 923$ (2012).

126. $I d . \S 924$.

127. $I d . \S 925$.

128. Id. $\S 941$. 
which may be modified until it is confirmed. ${ }^{129}$ Once the plan is confirmed, it is binding; the debtor is discharged of all debts other than those owed to a noknowledge entity. ${ }^{130}$ For confirmation, the plan must be both feasible and in the creditors' best interest, ${ }^{131}$ meaning it is possible to complete and debtors will receive what they reasonably can under the circumstances. At no point does the filing of a petition under Chapter 9 "limit or impair the power of a State to control" or expend resources in the exercise of governmental power over the municipality. ${ }^{132}$ Furthermore, absent debtor consent or pursuance of a confirmed plan, the court may not interfere with the governmental power, debtor revenue, or use and enjoyment of revenue-generating property. ${ }^{133}$

The protections in place for Chapter 9 are an order of magnitude greater than in every other Chapter. ${ }^{134}$ Not only are provisions in place to ensure use of Chapter 9 under the correct circumstances and only as a last resort, but precautions are also taken to ensure the federal government and other third parties cannot interfere with state sovereignty. These protections on all levels may be a clue as to the Congressional intent behind the Chapter, arguably to keep its use infrequent and limited to certain situations. Trailing this idea, it is important to look at current statistics before analyzing the costs, benefits, and reasons for filing.

\section{A Statistical Analysis of Chapter 9 Use}

Currently there are twenty-eight states that have an authorized definition of a municipality, allowing certain parties to seek relief under Chapter $9 .{ }^{135} \mathrm{~W}$ ithin those states, there are numerous actors who may seek relief; interestingly, the majority of petitions are not filed by entities traditionally thought of as the face of Chapter $9 .{ }^{136}$ The scale of recent filings has sparked a lot of media coverage regarding the Chapter's worth. ${ }^{137}$ However, the amount of attention is not proportional to the number of filings in comparison to other bankruptcy Chapters. ${ }^{138}$

Since the enactment of Chapter 9 in 1937 there have been 635 filings. ${ }^{139}$ Of

129. Id. $\S 942$.

130. Id. § 944 .

131. Id. § 943(b)(7).

132. Id. $\S 903$.

133. Id. $\S 904$.

134. See generally id. $\S \S 901-46$.

135. SpIOtTo, supra note 5, at app. D-3.

136. Id. at app. B (analyzing GDP of specific states in the U.S. typically thought of as financially unhealthy compared with the GDP of the following European countries: Portugal, Italy, Ireland, Greece, and Spain).

137. De Angelis \& Tian, supra note 2, at 311-12.

138. Id. at 312 .

139. Sріотто, supra note 5, at 43 (recorded from 1937 to Jan. 31, 2012). 
the 635 filings, 264 were filed between 1980 and 2012. ${ }^{140}$ Different municipal entities may be the benefactor of a Chapter 9 discharge, including but not limited to cities and counties, utility providers, hospitals, general-purpose districts, transportation entities, and school districts. ${ }^{141}$ Of these actors, the stereotypical Chapter 9 debtor is a city or county. ${ }^{142}$ However, as shown by the chart below, this is overwhelmingly not the case. ${ }^{143}$ In fact, the majority was filed by municipal utilities and hospitals, ${ }^{144}$ while media attention may have leaned solely to cities and counties.

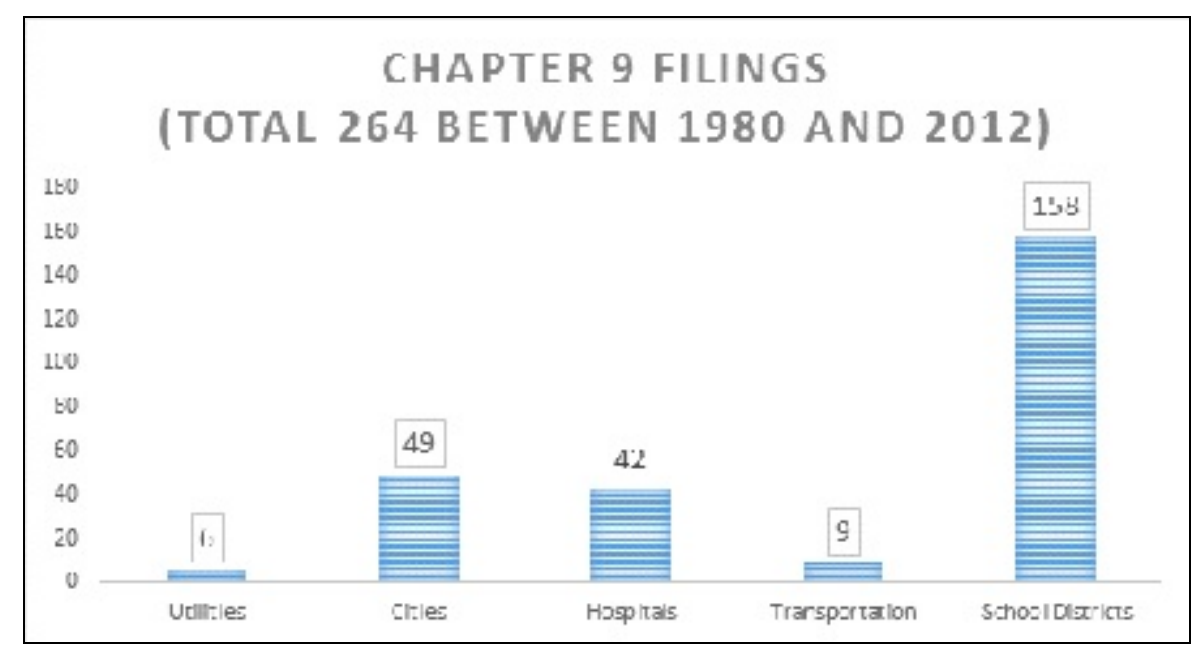

Further, as shown in the table below, the number of Chapter 9 filings pale in comparison to other forms of bankruptcy. ${ }^{145}$

140. Id. at app. C-1.

141. Id. at app. C-3.

142. See generally SpiotTo, supra note 5.

143. Id. at app. C-3 (representation of graph displayed).

144. Id.; see also De Angelis \& Tian, supra note 2, at 321-23.

145. U.S. Bankruptcy Courts-Business and Nonbusiness Cases Filed, by Chapter of the Bankruptcy Code-During the 12-Month Period Ending June 30, 2015, USCOURTS.GOV (June 30, 2015), http://www.uscourts.gov/statistics/table/f-2/bankruptcy-filings/2015/06/30 [http://perma.cc/5SDN-YDJZ] [hereinafter Bankruptcy Courts, June 30, 2015]; U.S. Bankruptcy Courts-Business and Nonbusiness Cases Filed, by Chapter of the Bankruptcy Code-During the 12-Month Period Ending December 31, 2014, USCourTs.gOv (Dec. 31, 2014), http://www. uscourts.gov/statistics/table/f-2/bankruptcy-filings/2014/12/31 [http://perma.cc/X5L8-79PU] [hereinafter Bankruptcy Courts, Dec. 31, 2014]; U.S. Bankruptcy Courts-Business and Nonbusiness Cases Filed, by Chapter of the Bankruptcy Code-During the 12-Month Period Ending December 31, 2013, USCOURTS.GOV (Dec. 31, 2013), http://www.uscourts.gov/statistics/ table/f-2/bankruptcy-filings/2013/12/31 [http://perma.cc/QRL5-Z43U] [hereinafter Bankruptcy 


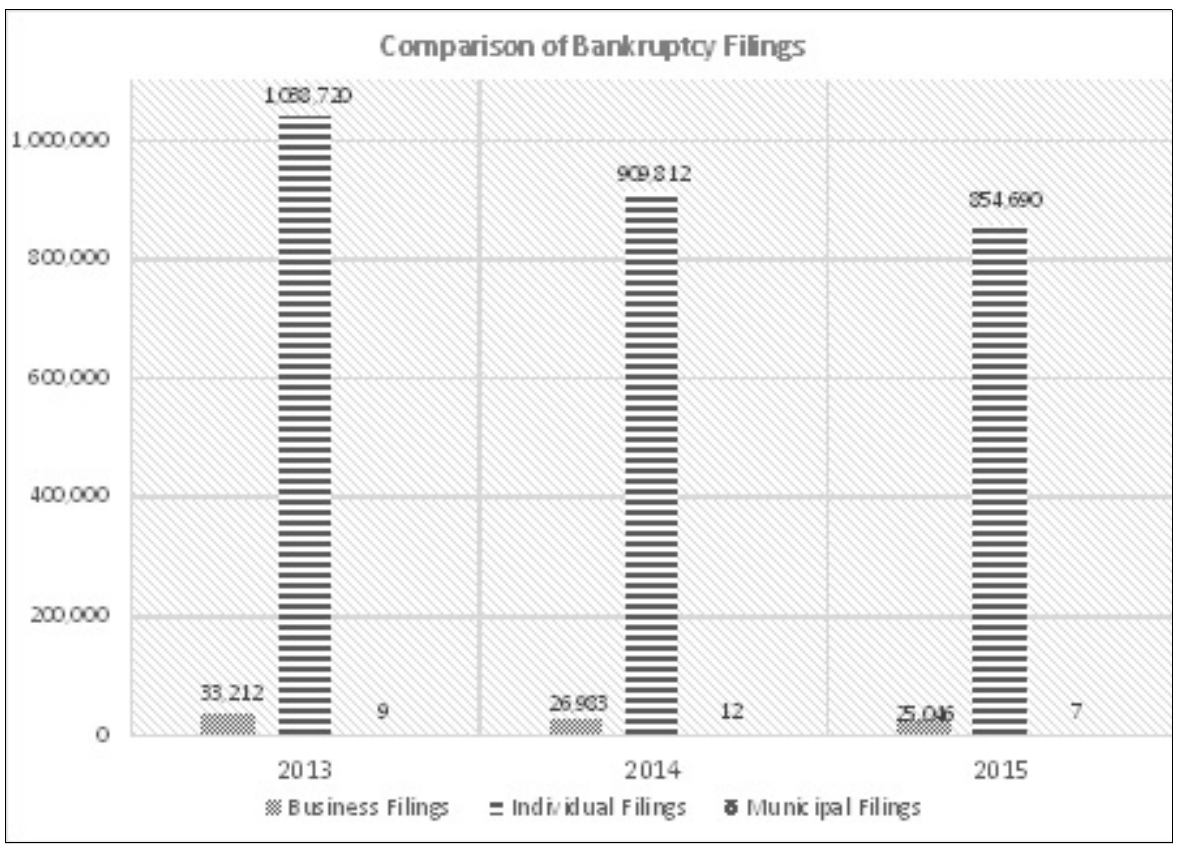

In sum, although Chapter 9 is invoked at a fairly steady rate, in light of aggregate bankruptcy usage, it is extremely rare. ${ }^{146}$ As well, the majority of benefactors to Chapter 9 relief are municipal utilities and hospitals-not cities or counties. ${ }^{147}$ The next part of this Note will analyze the costs and benefits of using Chapter 9 as well as the detrimental and beneficial reasons for filing for Chapter 9 relief as they relate to cities and counties.

\section{JUSTIFICATIONS FOR ARGUMENTS IN SUPPORT AND OPPOSITION TO CHAPTER 9}

Advocates for and against municipal bankruptcy make good arguments supporting their conclusion. As discussed above, although cities and counties are not the major benefactors of municipal bankruptcy, ${ }^{148}$ much of public discussion centers on concerns related to the minority of filings. By review of the specific reason behind these filings and their relative outcome, it is possible to predict the

Courts, Dec. 31, 2013].

146. See generally Bankruptcy Courts, June 30, 2015, supra note 145; Bankruptcy Courts, Dec. 31. 2014, supra note 145; Bankruptcy Courts, Dec. 31, 2013, supra note 145.

147. Sріотто, supra note 5, at app. C-3 (representation of graph displayed); see also De Angelis \& Tian, supra note 2, at 321-23.

148. SpiotTo, supra note 5, at app. C-3 (representation of graph displayed); see also De Angelis \& Tian, supra note 2, at 321-23. 
type of relief most likely to lead to success following bankruptcy. Contrasting the beneficial or detrimental reasons for filing with the costs and benefits can dispel or confirm concerns and should not be considered in isolation.

\section{A. Costs and Benefits of Chapter 9}

Some of the weightiest cost-benefit arguments surrounding Chapter 9 are drawn from the dichotomy between moral hazard and entrepreneurism. ${ }^{149}$ These notions constitute the undercurrent throughout the particular costs and benefits of Chapter 9 filings. An analysis of these theories is crucial to understanding the full importance of individual costs and benefits.

Moral hazard, more or less, represents the fear of a self-fulfilling prophecy. ${ }^{150}$ The fear is decisions will be made that are inclined to result in filing for Chapter 9 relief. ${ }^{151}$ The incentive to avoid a risky decision is far greater when bankruptcy relief is not available. ${ }^{152}$ Following this concern, Chapter 9 authorization will lead to less thought-out decisions and unforeseen repercussions will lead to a need to file. ${ }^{153}$ In stark contrast, the idea of entrepreneurism encourages the availability of relief from the results of decisions, finding a positive economic benefit. ${ }^{154}$ In essence, the inverse of moral hazard, the desire is to encourage originality and innovation and not curb decision makers' autonomy by lessening the burden of negative outcomes. ${ }^{155}$ For the sake of worthwhile discussion, it must be assumed advocates of the entrepreneurial model do not seek to allow risky and foolhearted attempts at solutions. Rather, after due diligence, where an unimagined result occurs, relief would be available to indemnify a municipality.

1. Costs of Chapter 9.- The costs associated with Chapter 9 mainly entail the externalities of stigma associated with the need for relief and the availability of

149. See generally Clayton P. Gillette, Fiscal Federalism, Political Will, and Strategic Use of Municipal Bankruptcy, 79 U. CHI. L. REV. 281 (2012) (describing that moral hazards are discouraging bailouts and leading to bankruptcy filing).

150. $I d$.

151. Id. at 330 .

152. Saul Mclead, Cognitive Dissonance, Simply Psychol. (2014), http://www. simplypsychology.org/cognitive-dissonance.html [https://perma.cc/J7YE-KCS4] (explaining methods by which cognitive dissonance may be reduced).

153. See generally id.; see also Gillette, supra note 149 (describing potential exploitation of bankruptcy over bailout).

154. See generally Ye Jia, The Impact of Personal Bankruptcy Law on Entrepreneurship, U. PRINCE EDWARD ISLAND (2010), https://www.frbatlanta.org/-/media/Documents/news/conferences/ 2010/small-business/jia.pdf [http://perma.cc/H56S-TP55].

155. Id.; Wei Fan \& Michelle White, Personal Bankruptcy and the Level of Entrepreneurial Activity 1, 5-11 (Nat'l Bureau of Econ. Research, Working Paper No. 9340, 2002), http://www. nber.org/papers/w9340.pdf [http://perma.cc/8EDF-UT7Y]; David Primo \& William Scott Green, Bankruptcy Law and Entrepreneurship, 1 ENTREPRENEURSHIP RES. J. Iss. 2, Art. 5, 1, 3-4 (2011) (describing changing perspective in bankruptcy). 
its use as a scapegoat to underlying fiscal decay. ${ }^{156}$ Many, if not all, municipalities, like consumers and businesses, require lending to sustain regular operations as well as fund expensive initiatives. ${ }^{157}$ The cost associated with lending is contingent upon market trends and availability, both of which impact the equilibrium interest rate. ${ }^{158}$ While market trends will fluctuate with other macro-economic forces, certain characteristics of a prospective debtor can make a significant impact. ${ }^{159}$ As a general matter, lenders evaluate a would-be debtor to determine the risk associated with making monies available, guessing the likelihood of return. ${ }^{160}$ Based on these results, a risk factor, typically a particular interest rate percentage, is imposed as a condition to lending. ${ }^{161}$ In situations where the probability of return is high, interest rates may be low or even at a prime level. ${ }^{162}$ In the alternative, where the prospect of return is slim, a higher interest rate risk premium is added, ${ }^{163}$ representing concern with lending funds. ${ }^{164}$ The interest rate also functions as a self-preservation mechanism; a lender can get a short-term gain in anticipation of a possible long-term loss. ${ }^{165}$ The anticipation of a possible loss due to availability of municipal bankruptcy embodies the concerns of moral hazard.

As interest accrues, the particular rate can add a significant expense to lending. ${ }^{166}$ No matter the particular identity of a prospective debtor, a history of financial failure and bankruptcy can significantly affect the credit rating and in turn raise interest rates. ${ }^{167}$ Nothing exempts municipalities from this trend and, in fact, creditor institutions have indicated that “[a] municipality's consideration of filing for bankruptcy protection is a grave credit concern." ${ }^{\text {168 }}$ As municipalities

156. See generally Rafael Efrat, The Evolution of Bankruptcy Stigma, 7 THEORETICAL INQUIRIES L. 365 (2006), http://www.csun.edu/ re38791/pdfs/Evolution\%20of\%20Bankruptcy\% 20Stigma\%20Article.pdf [http://perma.cc/QF8A-RWF8].

157. Sріотто, supra note 5, at 1-2; see also De Angelis \& Tian, supra note 2, at 312 (explaining municipalities' responsibility to provide public services despite not being structured to "generate profits").

158. Stanley L. Brue et al., Essentials of Economics 375-76 (3d ed. 2014).

159. See Ross ET AL., supra note 65, at 158 (discussing real rate of interest, rate of inflation, and interest rate risk).

160. Id.

161. BRUE ET AL., supra note 158, at 386 (see Figure 15.3 interest rate percentages); see also Ross ET AL., supra note 65, at 158 (describing interest rate as extra compensation for lending).

162. RosS ET AL., supra note 65, at 158.

163. Id.

164. Id. at $137-38,158$.

165. Id. at 160 (discussing how creditors demand higher yield to offset credit risk).

166. Id. at 88-89 (describing interest on interest and formula for compound interest to calculate value of investment).

167. Id.; Jeremy M. Simon, FICO Reveals How Common Credit Mistakes Affect Scores, CREDITCARDS.COM (July 13, 2010), http://www.creditcards.com/credit-card-news/fico-credit-scorepoints-mistakes-1270.php [https://perma.cc/A6EK-4UVG].

168. Richard J. Raphael et al., Fitch: The Perils of Considering Municipal Bankruptcy, Bus. 
are a fairly recognizable class of debtors, rightful apprehension exists to whether one default by a municipality may raise the cost of lending for all municipalities authorized as Chapter 9 debtors. ${ }^{169}$ Recent studies have indicated that when the risk to bondholders rises with respect to one municipality, creditors may demand higher rates from the entire sector. ${ }^{170}$ This indicates a contagion effect is possible and the spread of increased interest rates can happen where Chapter 9 relief is available and used. ${ }^{171}$

Aside from the fiscal repercussions, social stigma can have an impact, as well. ${ }^{172}$ Particular to municipalities, areas with a low credit rating may prompt concerns of a struggling economy. ${ }^{173}$ Not only can this impact the view of a locality, but it may also have a fiscal impact on tax revenues as individuals and corporations choose to reside elsewhere. ${ }^{174}$ Arguably the inverse is also possible where prevalence of Chapter 9 reduces social stigma. The cost of lending would likely remain the same in a situation such as this, but this is yet to be determined definitively. ${ }^{175}$

Finally, a significant cost to the overall health of a municipality's economy may be realized by use of bankruptcy as a guise. ${ }^{176}$ In situations where a municipality is sincerely struggling to make ends meet, a Chapter 9 filing can provide a scapegoat to the underlying problem. ${ }^{177}$ Allowing this to happen may cause re-filing needs. ${ }^{178} \mathrm{Or}$, if it is not addressed, may make matters worse such

WiRE (Jan. 27, 2010, 12:37 PM), www.businesswire.com/news/home/20100127006461/en/FitchPerils-Municipal-Bankruptcy\#.VhcdqXhN3zI [http://perma.cc/5B9U-G4LX].

169. Tracy Gordon, What the Stockton Municipal Bankruptcy Means, and Doesn't, BROOKINGS (Apr. 2, 2013), http://www.brookings.edu/research/opinions/2013/04/02-stockton-citybankruptcy-gordon [http://perma.cc/Z6FP-N94K].

170. Robert A. Kurtter \& Gail Sussman, Announcement: Moody's Examines Why Some California Cities are Choosing Bankruptcy, Moody's Inv. SERv. (Aug. 17, 2012), https://www. moodys.com/research/Moodys-examines-why-some-California-cities-are-choosing-bankruptcy-PR_253436 [http://perma.cc/9WR8-UUFL] (describing that "[a]cross-the-board rating revisions are possible").

171. $I d$.

172. See generally Efrat, supra note 156; Raphael et al., supra note 168 (describing stigma may wear off with increased discussion of bankruptcy).

173. Aimee Picchi, 10 Cities with the Worst Credit Scores, CBS News (Jan. 28, 2016, 6:00 AM), http://www.cbsnews.com/media/10-cities-with-the-worst-credit-scores/ [https://perma.cc/JCN8-VGCX].

174. Sріотто, supra note 5, at 6-7 (describing causes of defaults include population movement); Kurtter \& Sussman, supra note 170 (discussing California revenue loss in property and sales tax in housing market crash).

175. Kurtter \& Sussman, supra note 170.

176. De Angelis \& Tian, supra note 2, at 328-29 (describing Jefferson County, Alabama filing after negotiations raised legal issues of application).

177. See generally id. at 328-31 (explaining cases involving problematic features of special purpose vehicles of sewer system, incinerator plant, failure to pay into pension funds).

178. See generally $i d$. at 326-31 (discussing lengthy legal processes and multiple filings of 
that relief would do no good. ${ }^{179}$

2. Benefits of Chapter 9.-When circumstances give rise to the need for Chapter 9 relief, general debtor protections, as well as those protections particular to the municipal debtor, can provide solace from financial distress. ${ }^{180}$ When payment becomes delinquent, creditors engage in collection activities seeking a return on the outstanding obligation. ${ }^{181}$ At the time of filing a petition under Chapter 9, the automatic stay is implemented, suppressing these activities. ${ }^{182} \mathrm{In}$ certain instances the stay can be extremely valuable. ${ }^{183}$ In the case of Orange County, California, filing for relief froze accounts holding $\$ 7.6$ billion in local agency monies, leaving them beyond the reach of creditors. ${ }^{184}$ Absent the automatic stay, creditor litigation would likely have depleted the county's funds leaving little to conduct normal operations. ${ }^{185}$ As well, the automatic stay can be useful to block creditors from seeking a writ of mandamus instructing a municipality to levy taxes. ${ }^{186}$ In situations where all the municipality's assets are committed to carrying out public functions, the funds are exempt from execution. ${ }^{187}$ A creditor's only recourse is a judicial order to raise tax monies not used for a fiduciary responsibility, ${ }^{188}$ which are free for collection in support of debt repayment. ${ }^{189}$ The automatic stay frees a municipality from the possibility of being, "commanded to tax and tax again," in this way. ${ }^{190}$ Finally, the automatic stay provides a pardon from a municipality's obligation to make payments on debt while the case is pending. ${ }^{191}$ When a municipality simply cannot meet payment schedules, it may be in its best interest to not pay, while also avoiding interest and late fee expenses. ${ }^{192}$

In addition to removing the obligation to pay on existing contracts, Chapter

Chapter 9).

179. See generally id. (describing increased incurred financial burden and continued fiscal struggles).

180. See generally EPSTEIN ET AL., supra note 54.

181. Id. at 107-09 (describing collection efforts and automatic stay).

182. Id.; 11 U.S.C. $\S 362$ (2012).

183. See generally When Government Fails: The Orange County Bankruptcy a Policy Summary, PUB. Policy InST. CAL. (Mar. 18, 1998), http://www.ppic.org/content/pubs/op/OP 398OP.pdf [http://perma.cc/6J4B-XJJE].

184. Id. at $4-5$.

185. Id. (explaining funds frozen for local public agency including transportation, water, and sanitation).

186. See Ashton v. Cameron Cty. Water Improvement Dist., No. 1, 298 U.S. 513, 543 (1936).

187. 11 U.S.C. $\$ 522(2012)$.

188. Id.

189. Id. § 922.

190. Ashton, 298 U.S. at 534.

191. 11 U.S.C. $\S 362$ (a) (2012).

192. De Angelis \& Tian, supra note 2, at 331 (Prichard, Alabama case); see generally In re City of Vallejo, 403 B.R. 72 (Bankr. E.D. Cal. 2009). 
9 proceedings allow a municipality to renegotiate them. ${ }^{193}$ Once the debtor's plan has been confirmed it is binding on all creditors. ${ }^{194}$ This means that a municipality can be freed from contracts formerly detracting from its ability to remain solvent, over the objection of their creditors. ${ }^{195}$ For example, in the city of Vallejo, California, a municipality entered into pension and labor contracts that comprised a majority of the city's liabilities. ${ }^{196}$ The city of Vallejo was having trouble satisfying its other obligations while continuing operations; the contracts were simply "out of line with the city's budget realities." ${ }^{\text {"197 }}$ By filing for Chapter 9 relief, the city was able to void executory labor contracts and negotiate for a plan of payment more realistic for its financial situation. ${ }^{198}$ Though an inherent cost to the beneficiaries of those voided contracts, a single interest group is not the only dependent of the city. ${ }^{199}$ By having their contracts voided, the workers allowed the city to satisfy its other fiduciary obligations. ${ }^{200}$

Additionally, as an added benefit to filing, creditors are given priority for extending post-petition financing to a municipal debtor. ${ }^{201}$ This can be valuable when the market has rendered a financially distressed debtor too large a lending risk, meaning no funds are available to it. ${ }^{202}$ Furthermore, this protection is key to dispelling concerns of how operations will continue during the pendency of proceedings. ${ }^{203}$ Where the Code allows creditors an added protection in circumstances of post-petition lending, lines of credit or special revenues may be attained in contexts otherwise impossible. ${ }^{204}$

\section{B. Beneficial and Detrimental Reasons for Filing Chapter 9}

The need to file for municipal bankruptcy generally arises from financial distress. ${ }^{205}$ The impetus for such distress is an important consideration with regard to likelihood of success or relative failure at the outset of proceedings. ${ }^{206}$ In instances where the need to file for Chapter 9 arises from long-term financial misappropriation or fiscal decay, a net economic benefit is rarely realized by

193. See 11 U.S.C. $\S 365$ (2012).

194. Id. §§ 1126-29; see also id. § 943.

195. De Angelis \& Tian, supra note 2, at 326-28; see In re City of Vallejo, 403 B.R. at 72.

196. See In re City of Vallejo, 403 B.R. at 74-75.

197. De Angelis \& Tian, supra note 2, at 326-28.

198. See id.

199. Id.

200. See generally id.

201. 11 U.S.C. $\S 928(a)(2012)$.

202. EPSTEIN ET AL., supra note 54; see also 11 U.S.C. $§ 364$ (2012).

203. Id.

204. See generally In re County of Orange, 179 B.R. 185 (Bankr. C.D. Cal. 1995).

205. See generally EPSTEIN ET AL., supra note 54, at 15-36.

206. De Angelis \& Tian, supra note 2, at 334-35. 
seeking relief. ${ }^{207}$ Much of this trend is created by design. ${ }^{208}$ Congressional limitations are imposed on the bankruptcy court's reach and power over a municipality, pursuant to the Tenth Amendment. ${ }^{209}$ These restrictions eliminate its ability to "facilitate fiscal adjustment" or encourage budgetary decisions within the powers of the executive and legislature of a state. ${ }^{210}$ Though the benefit of renegotiation and discharge of certain obligations can provide a temporary stabilizing effect. ${ }^{211}$ Unless the debtor takes the initiative to continue making and implementing changes, Chapter 9 will not fix a municipality's core economic issues. ${ }^{212}$

Examples of such long-term fiscal decline normally include an atrophying tax base, increasing unemployment, and a deteriorating infrastructure. ${ }^{213}$ For instance, in Prichard, Alabama, discussed above, although bankruptcy proceedings conveyed a short-term benefit to the stability of the city, eight years later, Prichard refiled. ${ }^{214}$ This shows that although Chapter 9 allows temporary solace from financial distress, the court cannot restructure a fiscal entity to encourage improved finances in the future. ${ }^{215}$ Although Chapter 9's restrictions may be a comfortable notion of federalism, the detriment is true overhaul of a municipality's fiscal struggles is beyond its scope. ${ }^{216}$

In contrast to the foregoing examples, instances of one-time events causing need for financial relief tend to be the best candidates for economic recovery after bankruptcy proceedings. ${ }^{217}$ These are instances in which no need for fundamental changes are necessary. Under these circumstances, the economic benefit from Chapter 9 can be great; ${ }^{218}$ a perfect "tool" to adjust a municipality's debt, renegotiate insidious contracts, and provide protection from legal proceedings claiming assets. ${ }^{219}$ Such one-time occurrences can arise from a variety of situations. A good example is Orange County, California, where a poor use of strategic investments caused financial chaos. ${ }^{220}$ The decision making was not a systemic issue, but rather a sole occurrence that significantly hurt the county's fiscal stability. ${ }^{221}$ The county entered bankruptcy and within two years attained

207. Id. at 335-37.

208. Id.

209. See id.

210. Id.

211. Id.

212. $I d$.

213. Id.

214. See generally In re Jefferson Cty., Ala., 469 B.R. 92 (Bankr. N.D. Ala. 2012); De Angelis \& Tian, supra note 2, at 331, 335-37.

215. De Angelis \& Tian, supra note 2, at 335.

216. Id. at 331-35; see also 11 U.S.C. $\S \S 903-04$ (2012).

217. De Angelis \& Tian, supra note 2, at 334-35.

218. See generally In re Cty. of Orange, 183 B.R. 609 (Bankr. C.D. Cal. 1995).

219. De Angelis \& Tian, supra note 2, at 330-31; Charbonneau Interview, supra note 116.

220. See generally In re County of Orange, 183 B.R. at 609.

221. De Angelis \& Tian, supra note 2, at 326-28. 
an AA bond rating. ${ }^{222}$

The overall success or failure of a Chapter 9 bankruptcy proceeding has a direct connection to the reasons its relief is sought. In the same vein, the respective costs and benefits associated with a municipal filing may be more or less salient depending on the conditions leading to a need for relief. The next part of this Note analyzes Indiana's finances to determine what reasons for filing are likely to occur. Following this analysis will be an overview of the current system for relief in Indiana and a conclusion to whether a Chapter 9 authorization could be useful and, if so, how it should be drafted.

\section{CHAPTER 9 AND INDIANA}

Senate Bill No. 105 was introduced in 2011, offering to amend current legislation regarding the Distressed Unit Appeal Board (discussed below). ${ }^{223}$ In part, the bill offered an appointed Emergency Manager the option of seeking bankruptcy protection. ${ }^{224}$ The bill did not pass, but author and chief proponent Senator Ed Charbonneau ( $\mathrm{R}$ - Valparaiso) has indicated he will continue trying. ${ }^{225}$ Looking to the recent Chapter 9 filing in Detroit, Michigan, Charbonneau sees a need to have measures in place to address a similar situation, should it arise. ${ }^{226}$ Charbonneau is not alone in his efforts. Other local officials like Rhonda Cook, Director of Governmental Affairs for the Indiana Association of Cities and Towns, stated, "[i]t's very possible," that a local unit or political subdivision would experience a need for Chapter 9. ${ }^{227}$ In opposition, local politician James Brainard (Mayor of Carmel, Indiana) stated that the "specter of bankruptcy" is far from a pending reality and an unnecessary legislative allowance. ${ }^{228}$ Similarly, local government financial manager Curtis Coonrod (CPA) says he does not anticipate a scenario wherein a municipality could realize the need to "employ" Chapter 9.229 Part of the reasoning is due to provisions in the Indiana Constitution. ${ }^{230}$ In the early nineteenth century Indiana filed bankruptcy, and in

222. Id.

223. S.B. 105, 170th Leg., 1st Reg. Sess. (Ind. 2011); Charbonneau Interview, supra note 116.

224. S.B. 105, 170th Leg., 1st Reg. Sess. (Ind. 2011).

225. Charbonneau Interview, supra note 116; Indiana Senator to Push for Municipal Bankruptcy Law, IND. Bus. J. (Aug. 3, 2013), http://www.ibj.com/articles/42831-indiana-senatorto-push-for-municipal-bankruptcy-law [http://perma.cc/GF2X-75MY].

226. Charbonneau Interview, supra note 116; Indiana Senator to Push for Municipal Bankruptcy Law, supra note 225.

227. Jon Seidel, 'Municipal Bankruptcy Bill' Not About Gary, Author Says, Ind. Econ. Dig. (Jan. 24, 2011), http://www.indianaeconomicdigest.net/main.asp?SectionID=31\&subsectionID= 198\&articleID=58103 [https://perma.cc/B7HQ-H2LD].

228. Telephone Interview with Mayor James Brainard, Mayor of Carmel, Ind. (Feb. 4, 2016) [hereinafter Brainard Interview].

229. Telephone Interview with Curtis Coonrod, CPA, C.L. Coonrod \& Company (Feb. 8, 2016) [hereinafter Coonrod Interview].

230. Brainard Interview, supra note 228; Coonrod Interview, supra note 229. 
1851 redrafted its constitution, including a qualified prohibition on incurring debt. ${ }^{231}$ The clause states, "No political or municipal corporation in this State shall ever become indebted, in any manner or for any purpose to an amount, in the aggregate, exceeding two per centum on the value of the taxable property within such corporation ...." ${ }^{232}$ To be sure, economic development is still viable in Indiana through classification of improvement projects as leases. ${ }^{233}$ However, the limitation has been helpful in avoiding financial trouble by allowing Indiana to incur only such debt as is necessary to pay interest, meet causal deficits in revenue, repel insurrection, or otherwise provide for public safety. ${ }^{234}$

With this backdrop, it appears Indiana has a predisposed aversion to municipal bankruptcy. ${ }^{235}$ However, Senator Charbonneau maintains that although the bill would allow such relief, the intent when drafting was to incite fiscal reform and encourage decision making and tough problem solving, ${ }^{236}$ emphasizing that bankruptcy relief should be a "tool" of last resort. ${ }^{237}$ Evaluation of the economic climate in Indiana, the impact of circuit breaker tax caps on local budgets, and the aid currently available from the Distressed Units Appeal Board is necessary to evaluate whether Chapter 9 is worthwhile in Indiana and if so under what circumstances.

\section{A. Indiana's Economic Environment}

From the thirteenth-largest city in the nation, Indianapolis, ${ }^{238}$ to small rural communities in Union and Ohio counties, ${ }^{239}$ the Lake County areas of Gary and Hammond, and college towns of Bloomington and Lafayette, Indiana's municipalities are arguably as diverse as it gets. With this diversity comes a varying need for levy to fund a locality's budget. ${ }^{240}$ As a general matter, a

231. Brainard Interview, supra note 228; Coonrod, Interview, supra note 229; Andrea Neal, Indiana at 200 (37): 1851 Constitution Kept Us Debt Free, InD. PoL'Y Rev. (Nov. 3, 2014), http://inpolicy.org/2014/11/indiana-at-200-37-1851-constitution-kept-us-debt-free/ [http://perma.cc/2HPC-NE7P].

232. IND. CONST. art. $13, \S 1$.

233. Brainard Interview, supra note 228.

234. Neal, supra note 231.

235. Brainard Interview, supra note 228.

236. Charbonneau Interview, supra note 116; Indiana Senator to Push for Municipal Bankruptcy Law, supra note 225; Seidel, supra note 227.

237. Charbonneau Interview, supra note 116.

238. The Largest US Cities: Cities Ranked 1 to 100, City Mayors StATs., http://www. citymayors.com/gratis/uscities_100.html [perma.cc/6W7L-V256] (last visited Feb. 1, 2017).

239. See Annual Estimates of Residential Population, U.S. Census Bureau, http://www.census.gov/quickfacts/chart/PST045215/18097 [perma.cc/2BDD-YGA7] (last visited Feb. 3, 2017).

240. Interview with David P. Reynolds, Majority Senior Fiscal Analyst, Indiana Senate, in Indianapolis, Ind. (Jan. 18, 2016) (on record with author) [hereinafter Reynolds Interview]; see also John Stafford, Ind. Fiscal Policy Inst., The Fiscal Health of Indiana's Larger 
municipal budget is created and then compared to the assessed value of the property within its jurisdiction. ${ }^{241}$ Based on this comparison, a percentage of that value is rendered, which is the amount citizens of a locality are expected to pay. ${ }^{242}$ Indiana's legislature has taken a variety of steps to keep the percentage at a reasonable level. ${ }^{243}$ In particular, "circuit breaker" tax caps were established by means of constitutional amendment. ${ }^{244}$ Since 2010 they have served their purpose, but have an extremely varied impact among different communities. ${ }^{245}$ Circuit breaker tax caps set percentages for various types of land, beyond which a municipality may not tax its citizens. ${ }^{246}$ While an immediate financial benefit for citizens,${ }^{247}$ the amount not collected is lost revenue for the municipality and in 2015 amounted to $\$ 727$ million, equal to over ten percent of tax revenue across the state. ${ }^{248}$ The reduced collection is applied in proportion to its impact on the taxing district. ${ }^{249}$ Meaning, the burden of the levy reduction falls on local governments because state revenues are not used to compensate localities for the loss. ${ }^{250}$ Based on the respective valuations of property in localities across the state, the tax caps can have a wide-ranging effect. ${ }^{251}$ In 2015 , Delaware County lost more than twenty-two percent of its budget, while Franklin and many other counties lost less than one percent to the caps. ${ }^{252}$ The loss is proportional to the amount required to fund necessary services, so areas requiring more services feel a larger impact. ${ }^{253}$ For instance, within Delaware County, Perry, Liberty, Monroe, and Hamilton townships lost less than one percent of their budget, while Muncie Community School Corp., Muncie Sanitary, and Muncie Public Transportation

MuniciPALities 44 (2015), http://indianafiscal.org/resources/IFPI\%20Fiscal\%20Health\%20of\% 20Cities\%20FINAL.pdf [https://perma.cc/T9RP-EH95].

241. Reynolds Interview, supra note 240.

242. Id.

243. $I d$.

244. Id.; see also Dep’t local Gov't Fin., Circuit Breaker Caps Fact Sheet (2013), http://www.in.gov/dlgf/files/CircuitBreakerFactSheet.pdf [https://perma.cc/NKE3-YH3T].

245. Reynolds Interview, supra note 240; see also Legislative SERV. Agency, Historical and Estimated Future Circuit Breaker Credits (2015).

246. Larry Deboer, Ind. Fiscal Policy Inst., What We Know About Indiana's PROPERTY TAX CAPS (2015), http://indianafiscal.org/resources/IFPI\%20Property\%20Tax\%2 0Report\%20FINAL.pdf[https://perma.cc/F9M9-WEC7]; see also DEP'T LoCAL Gov'T FIN., supra note 244.

247. STAFFORD, supra note 240 , at 44 .

248. DEBOER, supra note 246, at 1.

249. Earl M. Ryan, Ind. Fiscal Policy Inst., Property Tax Reform in Indiana 15 (2010).

250. Id.

251. See DeBoer, supra note 246, at 18.

252. Reynolds Interview, supra note 240; see also LegisLative SERV. AgENCy, supra note 245.

253. Reynolds Interview, supra note 240. 
lost more than forty percent. ${ }^{254}$ Likewise, in Lake County, Gary Civil City lost thirty-nine percent of its budget and Gary Community School Corporation lost thirty percent while many other townships and municipalities were barely affected ${ }^{255}$ Similar trends are present across Indiana. ${ }^{256}$

The system of tax caps in conjunction with the recession has affected the local municipal finances of older industrial communities more than residential and university areas. ${ }^{257}$ A municipality's relationship with decreases in tax revenue and the larger economic environment is directly correlated to its fiscal capacity, determining the ability to fund important services. ${ }^{258}$ In particular, six Indiana municipalities (Gary, Hammond, South Bend, Anderson, Muncie, and Terre Haute) fall into a category of "concern," with less than ninety percent capacity. ${ }^{259}$ The majority of these six areas have the highest loss of tax levy from circuit breaker tax caps as well as the highest property tax rates. ${ }^{260}$ In stark contrast, the "collar" of Marion County (Noblesville, Carmel, Fishers, and Greenwood) is in the most favorable position for fiscal capacity. ${ }^{261}$ At bottom, the impact of legislation has a varied effect based on locality-specific factors. ${ }^{262}$ Whether a municipality is one of "concern," the circuit breaker tax caps prove to be a substantial obstacle; likewise, municipalities may desire to circumvent their impact. ${ }^{263}$ Several avenues exist depending on the qualifications of a municipality. ${ }^{264}$

Available to all municipalities is a local option income tax. ${ }^{265}$ By use of this tool, units have the ability to create additional tax revenue to offset a loss from circuit breakers. ${ }^{266}$ Municipalities may impose the local option income tax for levy freezes, property tax relief, or public safety. ${ }^{267}$ By either holding property taxes constant and replacing the revenue, buying down property taxes, or raising funds for police, fire, and other safety services, a municipality can circumvent the effect of tax caps. ${ }^{268}$ However, as Senate Majority Senior Fiscal Analyst David Reynolds indicates, a tension exists between state and local government. ${ }^{269}$ Local

254. Legislative Serv. Agency, supra note 245.

255. See generally id.

256. See generally id.

257. STAFFORD, supra note 240 , at 1 .

258. Id. at 33-35.

259. Id. at 46 .

260. Id. at 33 .

261. Id. at 44 (citing all areas at or above $100 \%$ fiscal capacity); Brainard Interview, supra note 228 .

262. Reynolds Interview, supra note 240; see also STAFFORD, supra note 240, at 44.

263. STAFFORD, supra note 240, at 46; Reynolds Interview, supra note 240.

264. STAFFORD, supra note 240, at 46; Reynolds Interview, supra note 240.

265. STAFFORD, supra note 240, at 46; Reynolds Interview, supra note 240.

266. STAFFORD, supra note 240, at 46; Reynolds Interview, supra note 240.

267. StAFFORD, supra note 240, at 46; Reynolds Interview, supra note 240.

268. STAFFORD, supra note 240, at 46; Reynolds Interview, supra note 240.

269. STAFFORD, supra note 240, at 46; Reynolds Interview, supra note 240. 
officials would rather not raise taxes this way as an unfavorable political move, but state officials would like to see the use of tools provided to offset revenue loss before allowing financial assistance. ${ }^{270}$ Nevertheless, under circumstances of shrinking employment and population within a municipality, the impact of appropriating through income taxes may be negligible. ${ }^{271}$

A second option, exclusive to school corporations, is a special referendum. ${ }^{272}$ Voters can elect to tack on extra monies beyond circuit breaker maximums as funding for particular initiatives. ${ }^{273}$ As Reynolds advocates, these special referenda should be available to less sympathetic municipalities, allowing a vote to appropriate for any specific need. ${ }^{274}$ Lastly, municipalities may appeal to the Distressed Unit Appeals Board ("DUAB") to seek oversight in a general financial restructuring. ${ }^{275}$

\section{B. Effectiveness of the DUAB}

In the 1980s, Gary, Indiana faced a drastically changing business environment as the United States Steel, Corp. truncated local operations. ${ }^{276}$ The burden fell on the municipality as many employees were out of work and consumerism fell. ${ }^{277}$ "Poor relief" systems were needed but were funded by property taxes, levied on the very citizens who needed the aid, rendering Gary essentially insolvent and a "distressed township." ${ }^{278}$ Although Gary was able to somewhat recover after years of supervision, the area was never able to fully bounce back. ${ }^{279}$ Evidenced in part by stigma associated with Senator Charbonneau's 2011 bill as solely for the benefit of his constituency, ${ }^{280}$ Gary's financial decay has resulted in budgetary appropriations for Gary's school districts and appointment of an Emergency Manager. ${ }^{281}$ In sum, the application of distressed unit legislation was and continues to be of some benefit to Gary. ${ }^{282}$

A municipal corporation or special taxing district may petition the DUAB for

270. STAFFORD, supra note 240, at 46; Reynolds Interview, supra note 240.

271. STAFFORD, supra note 240, at 46; Reynolds Interview, supra note 240.

272. STAFFORD, supra note 240, at 46; Reynolds Interview, supra note 240.

273. STAFFORD, supra note 240, at 46; Reynolds Interview, supra note 240.

274. STAFFORD, supra note 240, at 46; Reynolds Interview, supra note 240.

275. STAFFORD, supra note 240, at 46; Reynolds Interview, supra note 240.

276. Sullivan, supra note 17.

277. Id.

278. $I d$.

279. Id.

280. Charbonneau Interview, supra note 116; Seidel, supra note 227.

281. Pub. L. No. 213-2015, § 81 (May 2015).

282. Martin Interview, supra note 48; Carmen McCollum, State, District Looks at Getting Gary Schools out of \$23.7 Debt, IND. ECON. Dig. (July 2015), http://indianaeconomicdigest.com/ main.asp?SectionID=31\&subsectionID=198\&articleID=80378 [perma.cc/K984-JZD3]; Sullivan, supra note 17. 
classification as a distressed political subdivision. ${ }^{283}$ The conditions necessary for such classification are indicative of an extremely distraught unit, ${ }^{284}$ ailments reminiscent of the requirement of insolvency under Chapter $9 .^{285}$ The DUAB may designate a political subdivision "distressed" if one of many characteristics applies:

The political subdivision has defaulted in payment of principal or interest on any of its bonds or notes[,] . . has failed to make required payments to payroll employees[,] . . . has failed to make required payments to judgment creditors[,] . . . has accumulated a deficit equal to eight percent $(8 \%)$ or more of the political subdivision's revenues[,] . . . has carried over interfund loans for the benefit of the same fund at the end of two (2) successive years[,] . . . has been severely affected, as determined by the board, as a result of granting the property tax credits . . . ${ }^{286}$

Once considered "distressed," the DUAB then appoints an Emergency Manager who "assume[s] and exercise[s] the authority and responsibility" of the executive and fiscal body. ${ }^{287}$ Following appointment of the Emergency Manager, the distressed unit relinquishes all control over financial affairs. ${ }^{288}$ Although unable to levy taxes or impose fees, the Emergency Manager may review and develop a budget, make a plan for the payment of outstanding obligations, approve spending, renegotiate existing labor contracts, enter into new contracts, and reduce or suspend salaries. ${ }^{289}$ To terminate the distressed unit designation, a petition must be filed and the DUAB must find the conditions of distress no longer present. ${ }^{290}$

Initially, the requirements necessary for classification as a distressed unit are similar to those of insolvency under Chapter $9 .{ }^{291}$ But the requirements for "distress" are likely forcing municipalities to wait too long, rendering aid from the DUAB too little, too late. ${ }^{292}$ Expanding applicability of DUAB services to localities that do not meet conditions of distress may serve the dual purposes of rendering aid before it is too late without forcing politicians to relinquish control over their constituencies' finances to the Emergency Manager.

As well, the procedures and controls over a municipality given to the Emergency Manager are similar to those given to a bankruptcy court. ${ }^{293}$ At first glance, many of these powers are arguably considered costs as well as benefits

283. IND. CODE § 6-1.1-20.3-6.5 (2016); id. § 36-1-2-13; id. § 36-1-2-18.

284. Reynolds Interview, supra note 240.

285. See 11 U.S.C. $\S 109$ (2012).

286. IND. CODE $\S 6-1.1-20.3-6.5(\mathrm{a})(1),(2),(3),(5),(7),(8)(2016)$.

287. Id. § 6-1.1-20.3-8.5.

288. Reynolds Interview, supra note 240; see also IND. CoDE § 6-1.1-20.3-8.5 (2016).

289. IND. CODE $\S 6-1.1-20.3-8.5$ (2016).

290. Id. § 6-1.1-20.3-13.

291. See 11 U.S.C. (2012), passim.

292. Reynolds Interview, supra note 240; see IND. CODE § 6-1.1-20.3-6.5 (2016).

293. See 11 U.S.C. $\S \S 903-04$ (2012). 
of seeking Chapter 9 relief. ${ }^{294}$ More importantly, these powers go beyond Tenth Amendment restrictions on the federal government and judiciary, allowing control over finances traditionally handled by local government. ${ }^{295}$ One example of DUAB action beyond the Tenth Amendment is the grant of $\$ 2$ million to Beech Grove from the State Rainy Day Fund. ${ }^{296}$ Beech Grove, one of many school corporations burdened by tax caps, ${ }^{297}$ submitted a petition for relief to the DUAB, which was accepted on September $30^{\text {th }}, 2013 .{ }^{298}$ Recommending approval of the petition, board members cited Beech Grove's fiscal discipline and plans for future action. ${ }^{299}$ Beech Grove's financial renovation, spurred in part by the DUAB process, allowed a change in levy from decreasing more than seven percent in 2013 to increasing nearly five percent in 2014 and seven percent in $2015 .^{300}$ Prerequisites to spurring such innovation are not sanctioned activities of a federal court or the Bankruptcy Code. ${ }^{301}$ Without the use of powers beyond Tenth Amendment restrictions, Beech Grove's relative recovery may not have been possible.

In summary, the DUAB structure is a means to gaining relief and instituting financial reform, which is a useful function. ${ }^{302}$ Providing a similar approach to Chapter 9's financial restructuring, Indiana has taken steps beyond the Tenth Amendment purview of the Bankruptcy Code. ${ }^{303}$ Even still, a loosening of the pre-requisites to application may be useful to allow municipalities a chance to

294. See generally IND. CoDE § 6-1.1-20.3-8.5 (2016); Gillette, supra note 149, at 327; see also Primo \& Green, supra note 155 , at 3.

295. See In re City of Detroit, 504 B.R. 97 (Bankr. E.D. Mich. 2013); see also U.S. ConsT. amend. X.

296. Order Approving Beech Grove City Schools' Petition for Relief, Distressed Unit Appeals Bd. (Sept. 30, 2013), http://www.in.gov/dlgf/files/DUAB_-_Beech_Grove_City_Schools_ Approval.pdf [perma.cc/HE3X-KDMR].

297. Kyle Stokes, 'The Pain Is Not Over' for Indiana District Hit by Tax Caps \& Busing Controversy, Ind. Pub. Media (Sept. 20, 2012, 1:29 PM), http://indianapublicmedia.org/ stateimpact/2012/09/20/the-pain-is-not-over-for-indiana-district-hit-by-tax-caps-busingcontroversy/ [perma.cc/W7R9-N93S]; OfFICE OF Fiscal AND MGMT. ANALYSIs, 2015 Property TAX REPORT WITH COMPARISON TO 2014, at 230 (Oct. 2015).

298. Order Approving Beech Grove City Schools' Petition for Relief, supra note 296; Ind. Dep't Local Gov't Fin., Beech Grove City Schools Petition to Distressed Unit Appeals BOARD (2013), http://www.in.gov/dlgf/files/DUAB_-_Beech_Grove_City_Schools_06_28_13.pdf [perma.cc/NG4T-YKBD].

299. Order Approving Beech Grove City Schools' Petition for Relief, supra note 296; see also Ind. Ass'N Sch. Bus. OfFicials, Beach Grove City Schools: Facilities Maintenance with Less Revenue (Dec. 2013), http://www.indiana-asbo.org/wp-content/uploads/2014/07/12-11-13Keeley.pdf [perma.cc/T899-G4WN].

300. Office of Fiscal and Mgmt. Analysis, supra note 297.

301. See De Angelis \& Tian, supra note 2, at 313-314.; see also In re City of Detroit, 504 B.R. 97 (Bankr. E.D. Mich. 2013); see generally U.S. Const. amend X.

302. IND. CODE $\S 6-1.1-20.3-8.5$ (2016).

303. See In re City of Detroit, 504 B.R. at 97; see also U.S. Const. amend. X 
seek aid before conditions tantamount to insolvency are present. ${ }^{304}$ Lastly, the powers and restrictions found within the DUAB arguably indicate a lessening in Indiana's legislative distaste for the underlying notions of Chapter 9 relief.

\section{If Indiana Adopts Chapter 9, What Should It Look Like?}

Arguments for and against adoption of Chapter 9 on the state level may never be fully exhausted. It is, however, interesting to consider the minor differences between the DUAB structure Indiana has adopted and federal Bankruptcy Code relief. Arguably, the addition of a Chapter 9 automatic stay, plan confirmation over the dissent of creditors, and the discharge of debts could furnish a benefit to municipalities under certain circumstances. Should Indiana ever decide to adopt municipal bankruptcy, certain protections should be included to increase the likelihood of a municipality's financial success following the order for relief. These protections should be included in the definition of authorized municipalities and implicate actions taken prior to filing a petition, the effect of discharge, as well as post-relief activity. In light of the present DUAB procedures, a bankruptcy filing may not be advisable depending on the circumstances leading to financial difficulty. ${ }^{305}$ Accordingly, the type of debts leading the municipal bankruptcy should be considered, limiting availability to produce the best possible result.

Much of the concern surrounding Chapter 9 is the fear of municipal leadership making risky decisions and then reaching for a reset button when they fail. ${ }^{306}$ Implementing measures to be taken prior to filing for relief may work to lessen the risk of authorization. ${ }^{307}$ Essentially, if a municipality desires to qualify as a municipal debtor under Chapter 9, certain steps would need to be taken. Examples of such measures may include elimination of circuit breaker tax caps, use of local option income taxes, negotiation with current creditors, and seeking financial review by a neutral third party. Similar to relief from circuit breaker tax caps (discussed above), state officials would likely look more favorably upon a municipal petition after self-help measures were carried out. ${ }^{308}$

Once these pre-filing measures have been exercised and the bankruptcy process has begun, a legislature may desire to limit the effect of discharge, lessening the burden on creditors. Provisions for the mandatory minimum repayment, maintenance of certain contracts, and types of liabilities that may be discharged could work to lessen the sting associated with bankruptcy relief. Creditor protections for pension beneficiaries, public safety workers, and tort victims, by way of targeted denial from discharge, would render a public benefit and likely lessen opposition to the tool's passage. ${ }^{309}$

304. IND. CoDE § 6-1.1-20.3-6.5 (2016); Reynolds Interview, supra note 240.

305. Martin Interview, supra note 48.

306. Gillette, supra note 149, at 283.

307. Reynolds Interview, supra note 240.

308. Id.

309. Charbonneau Interview, supra note 116. 
Following the order for relief, continued outside involvement in the municipality's financial affairs could be useful. By making all financial plans and actions of the municipality public record, holding town hall meetings, and appointing a neutral third party to evaluate all non-fiduciary spending and surviving contracts, a municipality would decrease the likelihood of further financial distress. ${ }^{310}$ Furthermore, by imposing time restrictions on when a municipality can re-file for Chapter 9, the legislature may increase the exercise of earnest efforts to leverage the relief and revamp a municipality's financial structure. ${ }^{311}$

In light of the current DUAB process compounded with Tenth Amendment restrictions on bankruptcy's effect, it appears that where the Code lacks authority to make local changes, the DUAB picks up the slack. ${ }^{312}$ Furthermore, as discussed earlier in the part of this Note providing an overview of beneficial and detrimental reasons for filing Chapter $9,{ }^{313}$ the most common instances where change beyond the Code's purview is needed are in instances of long-term financial decay. ${ }^{314}$ As long as the DUAB structure is present, the processes therein, either on their own or together with bankruptcy authorization, may be more constructive in creating financial health for the municipality moving forward. ${ }^{315}$ Likewise, a limitation on the authorization for filing Chapter 9 to instances of one-time occurrences leading to a need for relief could prove beneficial. Not only would the proper rehabilitation of a long-term financially distressed municipality be feasible and in line with the Tenth Amendment, but relief from unforeseen crippling one-time debt could also be possible. As Martin says in reflection of the differences between his time as Emergency Manager under Indiana's DUAB structure and experience working on Detroit, Michigan's bankruptcy, sometimes the debt is of a great enough magnitude that "there would be nothing a DUAB-type process could do," meaning a discharge is needed and "bankruptcy would be the only option, if it were available." 316

\section{CONCLUSION}

Indiana is not alone in feeling the repercussive effects of a recession. ${ }^{317}$ Changes in local government revenue and the necessity to keep expending on

310. See De Angelis \& Tian, supra note 2, at 313 (discussing limited effect of Chapter 9 due to Tenth Amendment restrictions).

311. EPSTEIN ET AL., supra note 54, at 91-100; see generally 11 U.S.C. $§ 109$ (2012).

312. Martin Interview, supra note 48.

313. See supra Part III.

314. De Angelis \& Tian, supra note 2, at 335-37.

315. Martin Interview, supra note 48.

316. $I d$.

317. See Mark Brown \& John Ketzenberger, Ind. Fiscal Policy Inst., Resetting INDIANA's FUTURE 12 (2010), http://www.indianafiscal.org/Resources/Documents/IFPI-FY-2010Closeout-Report.pdf [https://perma.cc/GTN5KZ9Y]. 
fiduciary operations has imposed a "new normal" upon public finance. ${ }^{318}$ Although many areas of Indiana have seemed to fair well through these trying economic times, ${ }^{319}$ some areas have not been so fortunate. ${ }^{320}$ Exemplified by Detroit, Michigan's state of social welfare prior to seeking bankruptcy relief, ${ }^{321}$ the impact of a distressed municipality is greater than a failing company or an insolvent individual. ${ }^{322}$ Although the creditors of each debtor will still face the effects of "equitable distribution," 323 a municipality's responsibilities to its citizenry seem to be of greater consequence. Compromise regarding the impact of a Chapter 9 filing can be handled through the inclusion of safeguards, qualifications, and conditions to the use of municipal bankruptcy. Nonetheless, when under financial distress, should the correct circumstances be present and bankruptcy relief a constructive means to returning financial stability and solvency, the "tool" should be available. ${ }^{324}$ After all, even following the most careful economics and acting in line with best practices should not excuse planning for the worst-case scenario while hoping for the best.

318. Id.

319. Brainard Interview, supra note 228; see also STAFFORD, supra note 240.

320. STAFFORD, supra note 240 , at 46.

321. See In re City of Detroit, 504 B.R. 97 (Bankr. E.D. Mich. 2013).

322. See SpiotTo, supra note 5.

323. EPSTEIN ET AL., supra note 54, at 37-52.

324. Charbonneau Interview, supra note 116; Martin Interview, supra note 48. 